\title{
PEMBENTUKAN KARAKTER KEWIRAUSAHAAN MELALUI PEMBINAAN SOFTSKILL PADA PEREMPUAN DI KELURAHAN LETTE
}

\author{
${ }^{1}$ Andi Ummul Khair, ${ }^{2}$ Asri dan ${ }^{3}$ Ahmad Firman \\ ${ }^{I}$ STIE Nobel Indonesia Makassar, andiummulkhair@stienobel-indonesia.ac.id \\ ${ }^{2}$ STIE Nobel Indonesia Makassar, drasriwawo01@gmail.com \\ ${ }^{3}$ STIE Nobel Indonesia Makassar, a_firman25@gmail.com
}

\section{Article history}

Received: 27 Agustus 2021 Revised: 30 September 2021

Accepted: 04 Oktober 2021

\section{Corresponding}

Author:

Andi Ummul Khair

STIE Nobel Indonesia

Makassar

Email:

andiummulkhair@stienobelindonesia.ac.id

\begin{abstract}
Abstrak
Pandemic Covid-19 menuntut perempuan untuk mampu bersikap cerdas dan proaktif dalam menghadapinya. Hal ini dapat menjadi pendorong bagi mereka untuk dapat mengambil peran penting dalam ketahanan keluarga baik secara psikologis maupun social ekonomi. Di Kelurahan Lette, nampak ibu rumah tangga pada umumnya memiliki faktor-faktor pendorong untuk berwirausaha disamping mereka juga memiliki potensi untuk berwirausaha baik secara mental dan materil. Oleh karena itu, dalam upaya mendorong perilaku berwirausaha kaum perempuan di wilayah ini maka Lurah Lette mengkolaborasikan pelatihan softskill pada pengabdian masyarakat ITB Nobel Indonesia dengan Dinas Koperasi Kota Makassar dimana kegiatan pengabdian ini memberi stimulasi pembentukan karakter kewirausahaan melalui metode experential learning pada pembelajaran orang dewasa (andragogi) dan Dinas Koperasi memberi informasi tentang bantuan dan program pemerintah untuk menggalakkan perilaku wirausaha di kalangan masyarakat Kota Makassar.

Kata kunci - karakter kewirausahaan, pembinaan softskill

\section{Abstract}

The Covid-19 pandemic nowadayas requires women to be smart and proactive in dealing with it. This can be a booster for them in taking part of this very important role in family resilience both psychologically and socioeconomically. In Kelurahan Lette, commonly housewives have the driving factors for doing entrepreneurship besides they have potential support both mentally and materially. Therefore, in the effort to encourage women's entrepreneurial behavior in this region, Lurah Lette collaborates on soft skills training with ITB Nobel Indonesia community service with Dinas Koperasi Makassar where the activity stimulates the formation of entrepreneurial character through experiential learning methods in adult learning (andragogy) whereas Dinas Koperasi provides information about government assistance and programs to promote entrepreneurial behavior among the people of Makassar City.

Keyword-entrepreneurship character, softskill development
\end{abstract}

\section{PENDAHULUAN}

Pandemic Covid-19 mengakibatkan banyak perubahan tatanan social ekonomi dalam masyarakat. berbagai tantangan dihadapi masyarakat di masa pandemi, antara lain tekanan psikis pribadi dan keluarga, livehood atau penghidupan ekonomi berkurang, ketidakpastian masa depan, keterbatasan ruang psikologis pribadi akibat berbagi ruang selama masa di rumah saja, kondisi keluarga dan hubungan antar anggota keluarga.

Tak hanya dari segi kesehatan dan bisnis, dampak dari pandemi saat ini juga dirasakan dalam keluarga, baik bagi psikologis orangtua maupun anak. Pembatasan Sosial Berskala Besar (PSBB) yang diterapkan pemerintah memaksa seluruh anggota keluarga menghabiskan waktu di rumah saja. Kegiatan yang sebelumnya selalu dilakukan di luar terpaksa dilakukan di rumah. Dengan kebijakan sosial distancing misalnya banyak karyawan yang di rumahkan tanpa pesangon, suami istri diam dirumah sepanjang hari tanpa penghasilan berpotensi terjadinya KDRT, double Barden, bahkan sampai kepada perceraian, sangat terasa sekali ketimpangan gender. 
Di samping itu, banyak perempuan yang harus mengalami pemutusan hubungan kerja atau dirumahkan, dan perempuan pekerja migran yang dipulangkan dari negara tempatnya bekerja. Berbagai permasalahan ini seringkali menimbulkan terjadinya tindak kekerasan terhadap perempuan, akibat lemahnya tingkat ekonomi, pendidikan, ataupun kondisi psikis mereka yang terguncang akibat berbagai masalah di pandemi saat ini. Selain itu, pentingnya melakukan edukasi sejak dini kepada anak-anak sekolah, terutama remaja putri sebagai persiapan untuk menjalani kehidupan pernikahan dan rumah tangganya kelak sehingga keadaan sekarang dapat menjadi pembelajaraan bagi mereka bagaimana peran perempuan sangat penting dalam ketahanan keluarga baik secara psikologis maupun social ekonomi.

Banyak yang bisa dilakukan para perempuan di wilayahnya masing-masing yang meliputi banyak bidang, terutama bidang sosial, ekonomi, kesehatan, hiburan, dan keamanan. Oleh karena itu, maka dibutuhkan partisipasi dari lembaga atau institusi yang terdorong oleh tanggung jawab moril untuk dapat memberikan pencerahan kepada para perempuan dan remaja putri sebagai tonggak berdirinya sebuah rumah tangga yang sehat secara psikologis maupun social ekonomi. Pihak-pihak tertentu seperti lembaga keuangan yang mewadahi kegiatan perekonomian masyarakat seperti perbankan dan Dinas Koperasi juga dapat mendukung mereka dengan menggalakkan program pemberdayaan ekonomi keluarga miskin, perempuan rentan dan terdampak Covid-19, serta perluasan program perlindungan sosial bagi keluarga miskin. Focus masalah pada kegiatan pengabdian ini adalah pemberdayaan ibu rumah tangga dan remaja putri dalam ketahanan ekonomi keluarga melalui pengembangan karakteristik kewirausahaan.

\section{Kewirausahaan pada Perempuan}

\section{a. Kondisi Ekonomi Perempuan di Indonesia}

Pada saat ini wanita tidak lagi hanya berperan sebagai ibu rumah tangga dan bergantung pada suaminya, tetapi juga sudah aktif berperan dalam berbagai bidang kehidupan, baik sosial, ekonomi, maupun politik. Wanita termasuk salah satu komponen penting yang juga diharapkan dapat mengisi pembangunan. Hal ini tidak terlepas dari jumlah penduduk Indonesia yang hampir $50 \%$ dari 250 juta jiwa penduduk adalah wanita (BPS, 2015). Partisipasi perempuan untuk menjadi mandiri dengan berwirausaha menunjukkan perkembangan yang signifikan. Data dari Kementrian Koperasi dan UKM pada tahun 2015 tercatat bahwa dari sekitar 52 juta pelaku UKM yang ada di seluruh Indonesia, sebanyak 60 persen usaha dijalankan oleh perempuan (Republika.co.id) Di daerah perkotaan, lapangan dan pengalaman kerja dalam sektor ekonomi formal sulit didapat oleh perempuan. Hal ini menyebabkan banyak perempuan, terutama dengan status janda, berada dalam posisi rawan. Akan tetapi, di beberapa daerah-daerah, perempuan secara ekonomi lebih aktif, kebanyakan mereka mampu meningkatkan penghasilan menambah pendapatan keluarga utamanya melalui usaha rumah tangga skala kecil. Berdasarkan hasil wawancara dengan beberapa wirausaha wanita terdapat bermacam-macam alasan yang mempengaruhi mereka berwirausaha. Diantaranya karena hobi, waktunya fleksibel, dan karena dorongan untuk membantu ekonomi keluarga/ membantu suami.

\section{b. Faktor-Faktor yang Mempengaruhi Kewirausahaan pada perempuan}

Menurut Anoraga (2004) faktor-faktor yang mempengaruhi wanita pengusaha (woman entrepreneur) dalam memulai usaha adalah sebagai berikut:

1) Faktor Kemandirian. Kemandirian adalah kemampuan untuk mengandalkan diri sendiri. Keterkaitan faktor kemandirian terhadap wanita pengusaha adalah dalam upaya menciptakan lapangan pekerjaan baru tidak bergantung dari orang lain.

2) Faktor Modal. Modal yang dimaksud adalah aset yang dimiliki saat ini berupa uang, kendaraan, rumah, emas, peralatan atau apa saja yang dapat digunakan sebagai modal dalam memulai usaha. Keterkaitan faktor modal terhadap wanita pengusaha adalah dengan menggunakan asset yang ada untuk dijadikan sebagai modal awal memulai usaha.

3) Faktor Emosional adalah suatu reaksi tubuh menghadapi situasi tertentu. Wanita pada umumnya lebih mudah mengendalikan emosionalnya daripada 
kaum laki-laki. Keterkaitan faktor emosional terhadap wanita pengusaha adalah dengan mampu mengendalikan emosionalnya sehingga bepengaruh baik terhadap pengambilan keputusan dalam mengelola usahanya.

4) Faktor Pendidikan adalah tempat dimana seseorang mendapatkan pengetahuan umum untuk mengembangkan bakat. Keterkaitan faktor pendidikan terhadap wanita pengusaha adalah dengan adanya pengetahuan seputar dunia usaha secara umum sehingga dapat membantu perempuan pengusaha untuk memulai dan mengelola usahanya semaksimal mungkin serta mampu mengubah suatu resiko menjadi suatu peluang bagi usahanya.

Sedangkan menurut Musrofi (2004) faktor-faktor yang mendorong seseorang menjadi wirausaha, dapat dikelompokkan menjadi tiga, yaitu:

1) Faktor Keluarga (Confidence Modalities) Karena terlahir dan dibesarkan oleh keluarga yang memililh tradisi kuat dalam berwirausaha, sehingga secara sengaja atau tidak sengaja cukup menjiwai pekerjaan semacam itu. Biasanya jenis usaha seperti ini akan diwariskan secara turun-temurun dari satu generasi ke generasi berikutnya. Untuk mengelola sebuah usaha dirasakan bukan merupakan sesuatu hal yang baru, dikarenakan telah terbiasa sedari kecil.

2) Faktor yang Disengaja (Emotion Modalities) Biasanya orang-orang seperti ini, awalnya tidak beniat ingin bekerja di kantor atau lebih dikenal sebagai pekerja atau orang gajian. Sebelumnya, mereka telah mempersiapkan diri untuk melakukan wirausaha. Orang-orang yang mempunyai alasan seperti ini besar kemungkinannya untuk sukses menjalankan bisnis. Karena mereka mencurahkan segenap pengetahuan dan tenaganya bagi usaha yang dirintisnya.

3) Faktor Pemaksa (Tension Modalities). Karena berbagai faktor seakan-akan dipaksa oleh keadaan sehingga tidak memiliki pilihan lain selain melakukan wirausaha. Alasan seperti ini biasanya berlaku bagi orang-orang yang menjadikan usahanya sebagai usaha sampingan. Maksudnya, mereka membangun suatu usaha bukan karena dari keinginan sendiri tetapi adanya faktor keadaan ekonomi ataupun hal lainnya.

\section{Karakter Kewirausahaan pada Perempuan}

Teori John Locke mengatakan bahwa semua pemikiran manusia berasal dari pengalaman terhadap kualita-kualitas primer yang ada pada alam ditangkap oleh panca indra dan direfleksikan oleh akal budi sehingga menjadi dasar dan pembentuk manusia (Rogers, 1994). Menurut Locke beberapa hal yang sudah ada sejak manusia dilahirkan adalah sense, memory dan personality. Dari pengertian ini maka dapat disimpulkan bahwa karakter dapat dibentuk melalui pengalaman. Sementara itu, menurut (Fay, 2017) kewirausahaan adalah penggabungan dua konsep penting, yaitu pengetahuan dan pengalaman yang dirasakan serta dilakukan melalui jatuh-bangun untuk menjadi terampil dan akhirnya menjadi sebuah keahlian dalam menjalankan roda bisnis. Oleh karena itu, pemberdayaan perempuan di masa pandemic dapat dilakukan melalui pembinaan karakter kewirausahaan pada perempuan melalui kegiatan pelatihan. Adapun Karakteristik wirausaha yang merupakan faktor internal yang menentukan kesuksesan usaha seperti: proaktif, memiliki visi, percaya diri, memiliki kebutuhan berprestasi, kreatif (Essel, 2019 \& (Paryono, 2010). Menurut (Indarto \& Santoso, 2020) bahwa karakteristik wirausaha mampu menjadi determinan terhadap kesuksesan usaha UMKM, sementara karakteristik usaha tidak terbukti berpengaruh terhadap kesuksesan usaha UMKM.

Pada perempuan di Kelurahan Lette, diidentifikasi keadaan perekonomian dan kewirausahaan sebagai berikut:

1) Perempuan di kelurahan Lette memiliki faktor-faktor pendorong dalam berwirausaha

2) Perempuan di kelurahan Lette memiliki potensi untuk berwirausaha baik secara mental dan materil

3) Perempuan di kelurahan Lette memperoleh support dari lingkungan dan pemerintah setempat untuk berwirausaha 
Atas dasar permasalahan yang terjadi pada mitra maka program PKM ini perlu dilakukan dengan:

1) Memberikan pembinaan kepada ibu rumah tangga agar dapat membudayakan sikap cerdas dalam keluarga di masa Pandemi Covid 19 (seperti pengelolaan cashflow keluarga, kemandirian pangan, penanganan anak dan psikologis keluarga)

2) Membina karakteristik kewirausahaan perempuan

3) Memberikan pencerahan tentang peluang-peluang bisnis home industry di masa pandemi

4) Memberikan pengarahan tentang kebijakan-kebijakan yang diberikan oleh pemerintah untuk membangkitkan produktifitas UMKM di masa pandemi.

\section{METODE PENELITIAN Sasaran Kegiatan PPM}

Dalam kegiatan pengabdian ini yang menjadi sasaran adalah ibu rumah tangga dan remaja putri di Kelurahan Lette Kecamata Mariso Kota Makassar yang terkeda dampak secara ekonomi dari Pandemi Covid 19. Kebanyakan dari mereka sebelumnya memiliki usaha menjual pakaian, sayur dan dagangan lainnya di pasar, atau menjalankan usaha kue di warung depan rumah mereka atau usaha bengkel, tambal ban yang macet yang tadinya dikelola oleh suami.

\section{Metode Kegiatan PPM}

Untuk memecahkan masalah yang sudah diidentifikasi dan dirumuskan tersebut di atas ,agar pendampingan dapat berjalan dengan lancar maka sebagai alternatif pemecahan masalah adalah sebagai berikut: pendampingan dilakukan dengan pendekatan individual dan klasikal. Pendekatan klasikal dilakukan pada saat pemberian teori dan pendekatan individual dilakukan pada saat pelatihan.

Awalnya peserta diberikan pemaparan tentang keadaan pandemic yang menuntut kecerdasan perempuan untuk menyikapinya dalam rumah tangga. Kemudian dilakukan pembinaan karakteristik kewirausahaan dengan menggunakan metode pembelajaran andragogi (Knowles, 1986) dimana kegiatan pelatihan dilakukan dengan menggunakan teknik keterlibatan diri (ego) peserta pelatihan melalui pembelajaran eksperensial yang dilakukan dalam prosedur sebagai berikut:
1. Penciptaan suasana kondusif dalam belajar melalui kegiatan yang melibatkan kerjasama dalam merencanakan program pelatihan ini

2. Menemukan kebutuhan pelatihan yakni melibatkan peserta dalam menyiapkan gambar-gambar, animasi dan display dalam penyajian materi.

3. Perumusan materi dan tujuan dalam memenuhi kebutuhan pelatihan

4. Merancang pola pelatihan dalam sejumlah pengalaman bagi peserta didik dimana peserta melakukan: demonstrasi untuk menunjukkan suatu proses kerja yaitu tahap-tahap, dan latihan yang digunakan untuk memberikan tugas kepada peserta pendampingan.

Setelah itu dilaksanakan sosialisasi tentang tentang peluang-peluang bisnis home industry di masa pandemi dan memberikan pengarahan tentang kebijakan-kebijakan yang diberikan oleh pemerintah untuk membangkitkan produktifitas UMKM di masa pandemi

\section{Langkah-Langkah Kegiatan PPM}

Beberapa langkah pendekatan yang dilakukan dalam melaksanakan kegiatan ini adalah sebagai berikut:

1. Kegiatan ini diawali dengan penjajakan di sekitar wilayah Pasar Lette, melihat situasi setelah adanya pandemi Covid 19

2. Mewawancarai para pedagang di pasar dan ibu-ibu yang tampak di rumahnya ada kegiatan usaha Melakukan pendekatan kepada RT dan salah satu orang yang berpengaruh di sekitar pasar Lette

3. Menyurat resmi kepada Pimpinan Kelurahan Lette untuk mengadakan kegiatan pengabdian masyarakat

4. Menerima persetujuan dari pihak kelurahan

5. Koordinasi kegiatan seminar di kantor kelurahan untuk penyampaian visi misi pengabdian masyarakat kepada masyarakat

6. Pelaksanaan seminar kewirausahaan yang dihadiri oleh Dinas Koperasi sebagai mitra

7. Pelaksanaan pelatihan pengembangan karakter kewirausahaan. 


\section{HASIL DAN PEMBAHASAN}

Sebuah penelitian di Harvard University Amerika Serikat menyatakan bahwa kesuksesan seseorang lebih ditentukan oleh soft skills ketimbang hard skills dimana soft skills menentukan 80 persen kesuksesan dan hard skills hanya 20 persen saja ("Antara Hard”, 2009). Hal ini juga berlaku dalam dunia kewirausahaan tentunya. Di tengah banyaknya pelatihan yang berorientasi pada hard skills dan kurikulum serta pendidiknya belum mampu mengakomodasi soft skills yang seharusnya diajarkan juga pada masyarakat ("Antara Hard", 2009).

Pelatihan Pengembangan Karakteristik Wirausahawan yang melatihkan lima karakteristik pokok di dalamnya memiliki dasar sebagai berikut:

a. Proaktif. Peserta pelatihan dalam kehidupan sehari-hari, tentu memiliki kecenderungan pola reaktif dalam menanggapi situasi. Kecenderungan tersebut diberi stimulasi untuk disadari dulu oleh peserta. Setelah itu, peserta diajak melihat potensi kekuatan diri untuk meningkatkan sikap proaktif, yaitu melalui kesadaran diri, imajinasi, suara hati, dan kehendak sehingga peserta pada akhirnya memiliki inisiatif dan memiliki pengendalian internal.

b. Memiliki Visi. Meski tidak semua individu memiliki tujuan hidup yang kuat. Peserta diberi stimulus untuk menyadari apakah mereka memiliki tujuan hidup yang kuat tersebut. Kemudian peserta diajak untuk "bermimpi", yaitu menciptakan tujuan hidup dan langkah-langkah konkret apa yang akan ditempuh serta kemungkinan-kemungkinan untuk mengatasi hambatan demi pencapaian tujuan tersebut sehingga peserta pada akhirnya mampu memiliki orientasi pada masa depan, memiliki keinginan mengorganisasi, toleransi atas ambiguitas, dan toleransi atas resiko.

c. Percaya Diri. Individu bertingkah laku karena dipengaruhi oleh masa lalunya. Kepercayaan diri juga dipengaruhi oleh pengalaman-pengalaman individu dalam hidupnya. Peserta kemudian distimulasi untuk dapat menggunakan pengalaman pribadi yang positif untuk meningkatkan kepercayaan dirinya
Volume 1 Nomar 1 Tahun 2021

sehingga pada akhirnya peserta yakin pada diri sendiri, independen, dan memiliki optimisme.

d. Memiliki Kebutuhan Berprestasi. Memberikan pengantar dengan mengungkapkan sebuah Pepatah China kuno "Tidak ada seorang pun yang bangun sebelum subuh selama tiga ratus enam puluh hari dalam satu tahun tidak mampu membuat keluarganya kaya raya". Pepatah tersebut berarti bahwa jika seseorang rajin, maka prestasi pun akan diraih. Beberapa penelitian empiris juga mengatakan hal yang serupa. Meta analisa terhadap penelitian-penelitian tersebut menemukan bahwa ada yang disebut dengan kaidah 10.000 jam, yaitu orangorang yang berprestasi dan biasanya terkenal telah melatih kemampuan yang membuat mereka berprestasi selama 10.000 jam dalam hidupnya sebelum ia sukses (Gladwell, 2009). Oleh karena itu, cara paling efektif untuk membuat individu memiliki kebutuhan berprestasi adalah dengan "memaksa" mereka untuk melatih kemampuan yang menjadi kelebihan mereka.

e. Kreatif. Kreativitas merupakan bagian kerja dari otak kanan. Secara teoritis, kreativitas dapat dibangkitkan dengan cara menenangkan otak kiri sehingga otak kanan dapat bekerja secara luar biasa dalam hal kreativitas. Kuncinya adalah melihat permasalahan yang menghambat kerja otak kanan tersebut, yaitu terlalu aktifnya otak kiri (Edwards, 1999; dalam Pink, 2008). Dengan mencoba melihat sesuatu dengan tidak baisa, hal-hal yang sudah biasa dapat dilihat kembali dengan cara yang lain sehingga peserta pada akhirnya dapat membaca peluang atau melihat dengan cara berbeda sehingga mampu melakukan inovasi.

Adapun proses pembelajaran andragogi yang menggunakan teknik Pembelajaran Eksperiensial oleh John Dewey yang menjadikan pengalaman sebagai dasar dari seluruh pembelajaran dengan menciptakan pengalaman buatan secara berkelompok yang memberi kesempatan peserta untuk menemukan sendiri makna hasil belajarnya dari pengalaman tersebut. Model ini bertumpu 
pada dua pilar aktivitas inti yaitu refleksi dan sharing peserta (Supratiknya, 2008). Model ini terdiri dari lima fase sebagai berikut (Pfeiffer \& Jones 1979; dalam Supratiknya, 2008):

a. Fase Mengalami (Experiencing): Peserta terlibat dalam suatu kegiatan dengan melakukan, mengamati, atau mengungkapkan sesuatu entah sendiri atau bersama kelompok.

b. Fase Membagikan Pengalaman (Publishing): Peserta diberi kesempatan membagikan apa yang dirasakan, dialami, diamati kepada peserta lain.

c. Fase Memproses Pengalaman (Processing): Peserta mendiskusikan pola dan dinamika kelompok yang muncul dari pengalaman dan sharing pengalaman yang dilakukan.

d. Fase Merumuskan Kesimpulan (Generalizing): Peserta diberi latihan untuk menyimpulkan poin-poin pembelajaran dari pengalaman yang dialami.

e. Fase Menerapkan (Applying): Peserta melakukan latihan tugas untuk menerapkan poin-poin pembelajaran yang telah diperoleh dalam hidup sehari-hari.

Fase-fase tersebut terangkum dalam gambar berikut:

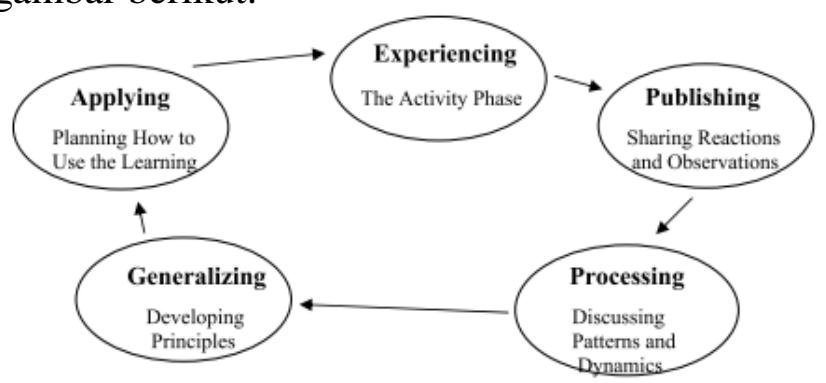

Gambar 1. Siklus Pembelajaran experensial (Paryono, 2010)

Kegiatan Pengabdian Masyarakat ini telah dilaksanakan oleh tim pelaksana Pengabdian Kepada Masyarakat ini, yaitu : Andi Ummul Khair,S.Pd.,M.Pd, Dr. Asri, S.Pd.,M.Pd. dan Dr. Ahmad Firman, SE.,M.Pd. selaku penulis dan pembicara yang menyampaikan materi menggali potensi perempuan dalam mengembangkan karakteristik kewirausahaan yang dimiliki untuk bangkit aktif sebagai penopang ketahanan ekonomi keluarga di masa pandemi.

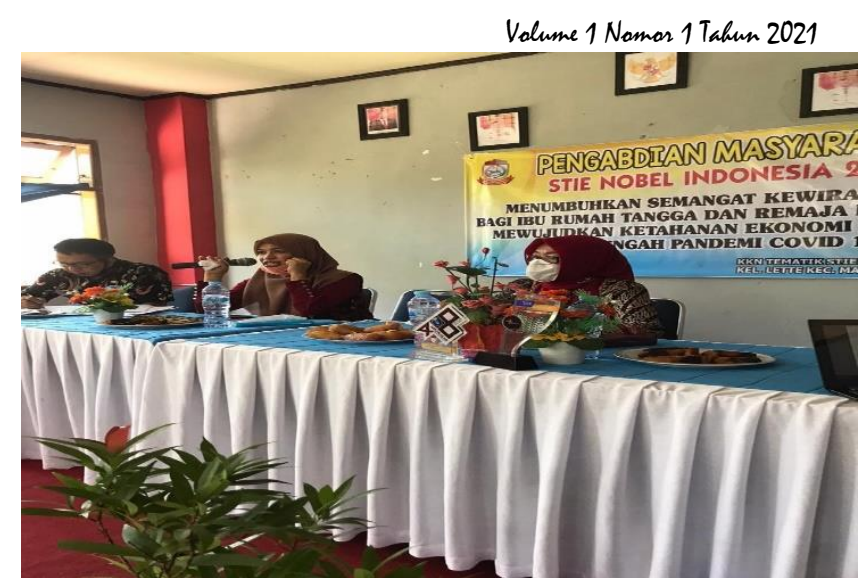

Gambar 2. Salah satu Narasumber Saat Memaparkan Materi

Segala kegiatan dilaksanakan dengan mengikuti standar protokol Covid-19 dimana dalam penyelenggarannya telah di lakukan pengawasan dan inspeksi oleh Satgas Covid-19 setempat. Sikap antusias Perempuan di Kelurahan Lette dapat juga dilihat dari antusias peserta seminar dan pelatihan. Respon balik dari peserta juga dapat terlihat dengan banyaknya pertanyaan dan keaktifan dalam melakukan latihan dan demonstrasi.

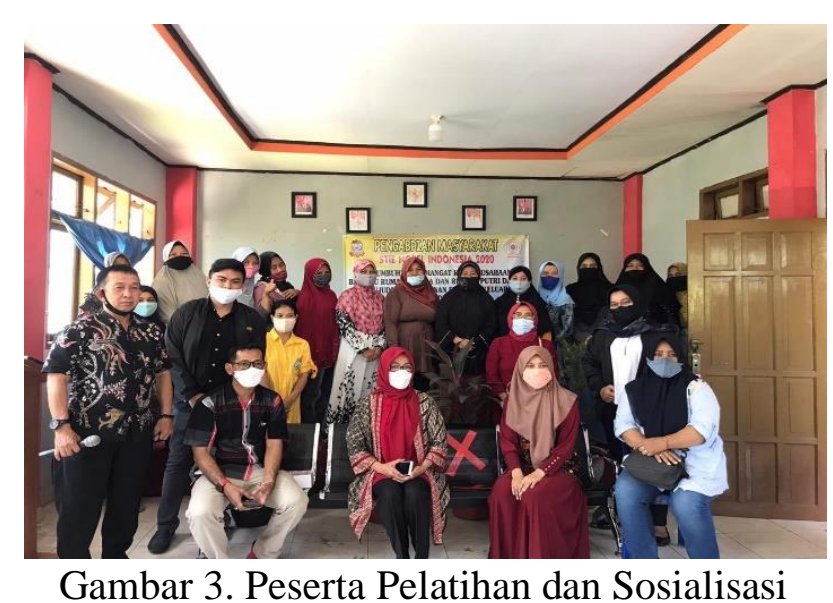

Hasil pelaksanaan kegiatan Pengabdian Pada Masyarakat secara keseluruhan dapat dilihat dari beberapa komponen berikut ini :

1. Ketercapaian Target Jumlah Peserta

Target peserta pelatihan atau sasaran kegiatan adalah perempuan/ibu rumah tangga yang tinggal dan merupakan warga Kelurahan Lette. Peserta yang hadir memang rata-rata adalah ibu rumah tangga yang belum mengambil keputusan untuk melakukan wirausaha.

2. Ketercapaian Tujuan

Ketercapaian tujuan dari kegiatan pengabdian pada masyarakat ini dapat diukur dengan tersampaikannya maksud yang sesuai dengan peta kegiatan di 
antaranya adalah:

1) Tersampaikannya materi pencerahan kepada ibu rumah tangga sehingga ada pemahaman sikap cerdas dalam keluarga di masa Pandemi Covid 19 (seperti pengelolaan cashflow keluarga, kemandirian pangan, penanganan anak dan psikologis keluarga).

2) Pemahaman peserta tentang karakter wirausaha yang diketahui melalui beberapa kegiatan latihan dan demonstrasi

5) Tersampaikannya materi tentang peluang-peluang bisnis di masa pandemi

6) Terarahkannya pengetahuan peserta tentang kebijakan-kebijakan yang diberikan oleh pemerintah dan lembaga lain untuk membangkitkan produktifitas UMKM di masa pandemi.

\section{Manfaat Kegiatan Pengabdian Masyarakat}

Manfaat yang diperoleh dari kegiatan ini adalah:

1. menggali potensi yang dimiliki oleh ibu rumah tangga dan remaja putri.

2. Kesetaraan gender memberikan banyak manfaat bagi dunia usaha berkat sudut pandang yang lebih menyeluruh dari perempuan.

3. Perempuan akan memahami pentingnya bersikap cerdas, manajemen finansial sebagai salah satu senjata melawan dampak finansial pandemi.

4. menjadi inspirasi bagi para wanita lainnya dalam memberi dampak yang luas, tetapi juga bersama-sama sekuat tenaga mengerahkan seluruh bentuk ketangkasan, empati dan kesiapsiagaan untuk menjadi penggerak perubahan di lingkungan masingmasing untuk melewati pandemi ini dengan baik

Dari kesimpulan tentang kegiatan pengabdian pada masyarakat diatas, maka ada beberapa saran yang perlu untuk diperhatikan dalam melakukan kegiatan pengabdian pada masyarakat di masa yang akan datang antara lain:

1. Agar pelaksanaan kegiatan pengabdian dapat mencapai sasaran yang diharapkan maka untuk kedepannya di butuhkan waktu yang lebih lama, dan pendampingan yang berkesinambungan dan perlu adanya kerjasama antara pihak Perguruan Tinggi dan Pemerintah.

2. Perlu pendampingan lebih lanjut yang dilakukan oleh pihak perguruan tinggi agar dalam melakukan pendampingan wirausaha tidak hanya memberi pembekalan hardskill tetapi juga softskill pada masyarakat.

\section{DAFTAR PUSTAKA}

Alvarez, Kay, Eduardo Salas, dan Christina M. Garofano. 2004. An Integrated Model of Training Evaluation and Effectiveness. Human Resource Development Review; Dec 2994;3, 4, pg. 385-416.

Munjiat Munawaroh, Hasnah Rimiyat Fajarwat. 2016. Kewirausahaan Untuk Program Strata 1. Penerbit : LP3M UMY

Fay, D. L. (2017). Konsep pengembangan kewirausahaan di Indonesia. DEEPUBLISH Edition, 1.

Indarto, I., \& Santoso, D. (2020). Karakteristik Wirausaha, Karakteristik Usaha Dan Lingkungan Usaha Penentu Kesuksesan Usaha Mikro Kecil Dan Menengah. Jurnal Riset Ekonomi Dan Bisnis, 13(1), 54. https://doi.org/10.26623/jreb.v13i1.2202

Paryono, H. Y. (2010). Efektivitas pelatihan pengembangan karakteristik wirausahawan pada mahasiswa. Universitas Sanata Dharma.

Myers, B. E. dan T Grady R. 2004. Conducting and Evaluating Professional Development Workshops using Experiential Learning. NACTA Journal, vol 48, p 27-32

Estepp, Ch. M et al. 2012. An Experiential Learning Model of Faculty Development to Improve Teaching, NACTA Journal, vol 56, p 79-86

Illeris, K. 2007. What do We Actually Mean by Experiential Learning?, Human Resource Development Review, vol 6, p 84-95

Proudman, B. 1997. Experiential Corporate Training:Working with the Whole Person. Conference Proceedings Asia Pasific Conference \& Exhibition on Experiential Learning'97

Ng, John dan Tan, Gilbert. 1997. Uses \& Abuses of Experiential LearningPerspectives from a Practitioner and An Academic. Conference Proceedings Asia 
Pasific Conference \& Exhibition on Experiential Learning'97

Rogers, G. A. J. (1994). Locke's Philosophy.

England: Clarendon Press Oxford.
Simmons, S. R. 2006. "A Moving Force":A Memoir of Experiential Learning. Journal of Natural Resources and Life Sciences Education, Vol.35, p. 132-139 